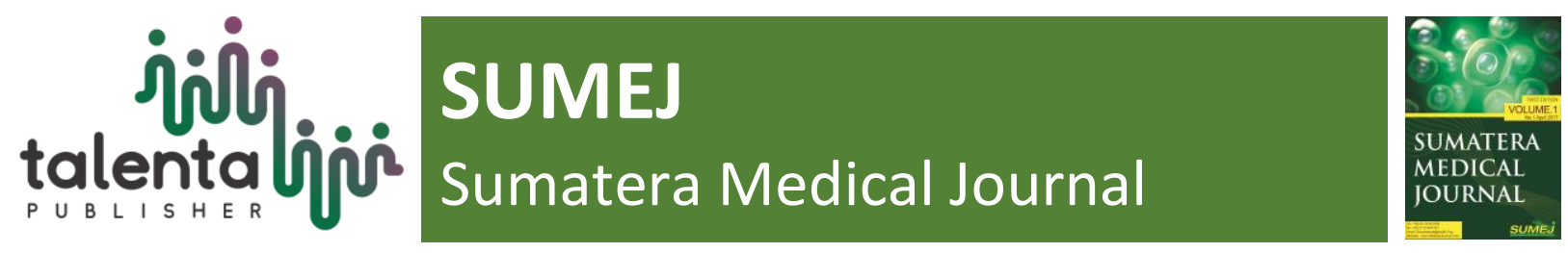

\title{
The Association Between Skin Types and Acne Vulgaris
}

\author{
A. B. P. Tamba ${ }^{*}$, N. K. Jusuf; \\ ${ }^{I}$ Faculty of Medicine, Universitas Sumatera Utara, Medan, Indonesia \\ ${ }^{2}$ Departement of Dermatology and Venereology, Universitas Sumatera Utara, Medan, Indonesia
}

\begin{abstract}
The skin problem often found on adolescents is acne vulgaris. The pathogenesis of acne vulgaris is multifactorial, from increased production of sebum, hyperproliferation of pilosebaceous follicles, colonization of Cutibacterium acnes, to inflammation process. The elevated sebum production which is often linked to oily skin type could result in acne vulgaris in adolescents. According to Baumann Skin Type, one of the parameters in categorizing skin type is having either oily or dry skin. Acne vulgaris is also found on dry skin. This research aims to find the association between skin types and acne vulgaris. It is an analitic research with cross-sectional method. The data were acquired from 93 students of SMA Santo Thomas 1 Medan who fulfilled the inclusion criteria with stratified random sampling method. The collection of data were primarily carried out with dermatology examination and Baumann Skin Type questionnaire to determine the skin types. Then, they were analyzed with Chisquare test to see the relationship between skin types and acne vulgaris. The obtained results show that $73(78,5 \%)$ out of 93 students suffered from acne vulgaris with predominance being female $(39,8 \%)$ than male $(38,7 \%)$, and those in 15-year age group $(38,7 \%)$. The most commonly observed skin type on samples is oily skin $(79,6 \%)$. The bivariate analysis with acquired $\mathrm{p}$-value of $0,002(\mathrm{p}<0,05)$ led to a conclusion that there is a significant association between skin types and acne vulgaris.
\end{abstract}

Keyword: Acne Vulgaris, Adolescent, Skin Types

Received 19 December 2019 | Revised 06 January 2020 | Accepted 18 January 2020

*Corresponding author at: Faculty of Medicine, Universitas Sumatera Utara, Medan, Indonesia

E-mail address: nitabella_tamba@ymail.com 
1. Introduction

Acne vulgaris is a chronic inflammation of pilosebaceous units marked with comedones, papules, pustules, nodules and cysts which could result in scars and pigment changes [1]. In Indonesia, acne vulgaris was found on an estimated $80 \%$ of adolescents. The incidence was ranging between $30-60 \%$ with the peak being in 14-17 years old on females and 16-19 years old on males [2]. A retrospective research at RSUP Haji Adam Malk Medan from January 2010 - December 2012 stated that the prevalence of acne vulgaris was $1,10 \%$ (182 patients). The cases were mostly found on females in 16-20 years of age and students [3].

On Bauman Skin Type, one of the parameters to determine the category of skin is having either oily or dry skin. Oily skin is recognized with high production of sebum. When the skin does not have enough sebum to prevent evaporation of water and the skin barrier is disturbed, the skin will be classified as dry. Increased sebum production is often interpreted as oily skin, thus the skin type could be accounted as a risk factor of acne vulgaris. Dry skin is identifiable with the disturbed lipid barrier around keratinocytes which augments the loss of transepidermal water [4]. Weakened skin barrier causes bacteria to easily enter and infect the skin and induce acne vulgaris [5]

\section{Methodology}

This is an analitic observational research with cross-sectional design, implemented on March to December 2019. The data were collected in July 2019 until the required number of samples was fulfilled at SMA Santo Thomas 1 Medan. The population includes every student either suffering or not suffering from acne vulgaris with stratified random sampling method.

The gathering of acne vulgaris and skin type data were executed with dermatology examination and questionnaire. The dermatology examination is to determine the status of acne vulgaris and skin type according to the characteristics of the skin. Oily skin is marked with larger pores, shiny skin, and dull appearance. Dry skin is observed with invisible pores, tight-feeling skin, bright face, and fine lines around the eyes, lips, and cheeks. The utilized questionnaire was Baumann Skin Type questionnaire which had been translated to Indonesian and validated with reliability score of 0,838. The questionnaire consists of 11 questions, with scales 1-4. The scores of 11-26 indicate dry skin while 27-44 suggest oily skin. 


\section{Result and Discussion}

The subjects of this research were students of SMA Santo Thomas 1 Medan in $10^{\text {th }}, 11^{\text {th }}$, and $12^{\text {th }}$ grades who fulfilled the inclusion criteria. The chosen subjects accounted for a total of 93 people with stratified random sampling. All the data were primary, obtained directly from the respondents with questionnaire and dermatology examination to determine the status of acne vulgaris. The characteristics of the subjects were described according to age, gender, skin type, and acne vulgaris status.

Table 1. The Distribution of Subjects' Characteristics Frequencies

\begin{tabular}{|c|c|c|c|}
\hline \multicolumn{2}{|l|}{ Characteristics } & \multirow{2}{*}{$\begin{array}{l}\text { Frequency } \\
48\end{array}$} & \multirow{2}{*}{$\begin{array}{l}\text { Percentage }(\%) \\
51,6\end{array}$} \\
\hline Age & 15 years old & & \\
\hline & 16 years old & 27 & 29 \\
\hline & 17 years old & 18 & 19,4 \\
\hline \multirow[t]{2}{*}{ Gender } & Male & 43 & 46,2 \\
\hline & Female & 50 & 53,8 \\
\hline \multirow[t]{2}{*}{ Skin type } & Oily skin & 74 & 79,6 \\
\hline & Dry skin & 19 & 20,4 \\
\hline Acne vulgaris & Positive & 73 & 78,5 \\
\hline status & Negative & 20 & 21,5 \\
\hline Total & & 93 & 100 \\
\hline
\end{tabular}

According to table 1, out of 93 samples, those in 15 year-old group had the highest distribution; as many as 48 people (51,6\%). It was followed by the 16 year-old group with 27 people (29\%) and the 17 year-old group with 18 people $(19,4 \%)$. Female subjects predominated with 50 people $(53,8 \%)$, while male ones accounted for as many as 43 people $(46,2 \%)$. The subjects with highest distribution according to skin types were those with oily skin, as many as 74 people $(79,6 \%)$, compared to those with dry skin; as many as 19 people $(20,4 \%)$.

From the research on 93 people, as many as 73 people $(78,5 \%)$ were suffering from acne vulgaris and 20 people were not. This is consistent with the researches of acne vulgaris prevalence on young adolescents which yielded an estimation of 79-95\% [6] and 80\% in Indonesia [2]. 
Table 2. The Characteristics of Acne Vulgaris Status According to Age

\begin{tabular}{lcccccc}
\hline & \multicolumn{3}{l}{ Acne Vulgaris Status } & \multicolumn{2}{c}{ Total } \\
\cline { 2 - 5 } Age & Positive & \multicolumn{2}{l}{ Negative } & & \\
\cline { 2 - 5 } & $\mathrm{n}$ & $\%$ & $\mathrm{n}$ & $\%$ & $\mathrm{n}$ & $\%$ \\
\hline 15 years old & 36 & 38,7 & 12 & 12,9 & 48 & 51,6 \\
16 years old & 24 & 25,8 & 3 & 3,2 & 27 & 29,0 \\
17 years old & 13 & 14 & 5 & 5,4 & 18 & 19,4 \\
\hline Total & 73 & 78,5 & 20 & 21,5 & 93 & 100 \\
\hline
\end{tabular}

According to the results on table 2, there were 73 people $(78,5 \%)$ who suffer from acne vulgaris from 93 samples. The age with highest frequency was 15 year-old $(38,7 \%)$, followed by 16 yearold $(25,8 \%)$, and 17 year-old group as the lowest (14\%). The onset of acne vulgaris is at the period of puberty. Acne vulgaris usually appears then when the sebaceous glands enlarge and produce more sebum than the usual, which could increase the bacteria amount [7].

Table 3. Characteristics of Acne Vulgaris Status According to Gender

\begin{tabular}{lllllll}
\hline & \multicolumn{3}{l}{ Acne Vulgaris Status } & \multicolumn{2}{l}{ Total } \\
\cline { 2 - 6 } Gender & \multicolumn{2}{l}{ Positive } & \multicolumn{3}{l}{ Negative } & \\
\cline { 2 - 6 } & $\mathrm{n}$ & $\%$ & $\mathrm{n}$ & $\%$ & $\mathrm{~N}$ & $\%$ \\
\hline Male & 36 & 38,7 & 7 & 7,5 & 43 & 46,2 \\
\hline Female & 37 & 39,8 & 13 & 14 & 50 & 53,8 \\
\hline Total & 73 & 78,5 & 20 & 21,5 & 93 & 100 \\
\hline
\end{tabular}

According to the results on table 3, the gender being affected by acne vulgaris mostly was female, accounting for $39,8 \%$, while males having acne vulgaris were $38,7 \%$. This results show that the female adolescents tend to have acne vulgaris earlier than male ones. The reason was the respondents being 15-17 year-old students. Semyonov, 2010 stated that acne vulgaris tended to appear faster on females (11 year-old) than males (12-13 year-old). The highest prevalence was found in 14-17 year age group on females and 16-19 year on males [2]. 
Table 4. The Characteristics of Skin Types According to Age

\begin{tabular}{|c|c|c|c|c|c|c|}
\hline \multirow{3}{*}{ Age } & \multicolumn{4}{|c|}{ Skin Types } & \multirow{2}{*}{\multicolumn{2}{|c|}{ Total }} \\
\hline & \multicolumn{2}{|c|}{ Oily Skin } & \multicolumn{2}{|c|}{ Dry Skin } & & \\
\hline & $\mathbf{n}$ & $\%$ & $\mathbf{n}$ & $\%$ & $\mathbf{n}$ & $\%$ \\
\hline 15 years old & 36 & 38,7 & 12 & 12,9 & 48 & 51,6 \\
\hline 16 years old & 23 & 24,7 & 4 & 4,3 & 27 & 29 \\
\hline 17 years old & 15 & 16,1 & 3 & 3,2 & 18 & 19,4 \\
\hline Total & 74 & 79,6 & 19 & 20,4 & 93 & 100 \\
\hline
\end{tabular}

According to the results on table 4, the highest prevalence of skin type was oily skin with 74 people while the ones with dry skin accounted for 19 people. Those with oily skin were mostly in 15 year-old group (38,7\%), followed by 16 year-old $(24,7 \%)$, and 17 year-old $(16,1 \%)$. The sebum secretion starts to increase from the age of 15 and will keep on increasing gradually until the age of 40 , which will then decrease [8].

Table 5. The Characteristics of Skin Types According to Gender

\begin{tabular}{lllllll}
\hline \multirow{2}{*}{ Gender } & \multicolumn{2}{l}{ Skin Type } & \multicolumn{3}{l}{ Total } \\
\cline { 2 - 6 } & \multicolumn{2}{l}{ Oily Skin } & \multicolumn{2}{l}{ Dry Skin } \\
\cline { 2 - 6 } & $\mathbf{n}$ & $\mathbf{\%}$ & $\mathbf{n}$ & $\mathbf{\%}$ & $\mathbf{N}$ & $\mathbf{\%}$ \\
\hline Male & 33 & 35,5 & 10 & 10,8 & 43 & 46,2 \\
\hline Female & 41 & 44,1 & 9 & 9,7 & 50 & 53,8 \\
\hline Total & 74 & 79,6 & 19 & 20,4 & 93 & 100 \\
\hline
\end{tabular}

According to the results on table 5, females with oily skin (41\%) were more common than males with oily skin (33\%). On dry skin category, the males account for 10 people while females were as many as 9 people. These results were different from those of the research by Abdallah et al which showed that the production of sebum were higher on males compared to females. This was consistent with the theory stating the production of sebum was affected by androgen hormones such as testosterone and dehydroepiandrosterone [9]. 
Table 6. The Association Between Skin Types and Acne Vulgaris

\begin{tabular}{|c|c|c|c|c|c|c|c|c|}
\hline \multirow{3}{*}{ Skin Types } & \multicolumn{4}{|c|}{ Acne Vulgaris Status } & \multirow{2}{*}{\multicolumn{2}{|c|}{ Total }} & \multirow{3}{*}{$\begin{array}{l}\mathbf{p} \\
\text { value }\end{array}$} & \multirow{3}{*}{ OR } \\
\hline & \multicolumn{2}{|c|}{ Positive } & \multicolumn{2}{|c|}{ Negative } & & & & \\
\hline & $\mathbf{n}$ & $\%$ & $\mathbf{n}$ & $\%$ & $\mathbf{n}$ & $\%$ & & \\
\hline Oily Skin & 63 & 67,7 & 11 & 11,8 & 74 & 79,6 & & \\
\hline Dry Skin & 10 & 10,8 & 9 & 9,7 & 19 & 20,4 & 0,002 & 5,155 \\
\hline Total & 73 & 78,5 & 20 & 21,5 & 93 & 100 & & \\
\hline
\end{tabular}

According to table 6, it was found that the students with oily skin suffered from acne vulgaris $(67,7 \%)$ more than those with dry skin did $(10,8 \%)$. In analysing the results of this research, the Chi-square test was used as the bivariate analysis to see the effects of each independent variable to the dependent variable. Based on the analysis, there is a significant relationship between skin types and acne vulgaris and those with oily skin are 5 times more prone to acne vulgaris ( $\mathrm{p}$ value $0,002<\alpha=0,005$ and $\mathrm{OR}=5,155)$. The amount of sebum production is stated to be linear to the characteristics of oily skin where the skin with high sebum production is observed as oily skin and vice versa. The increased sebum production may be affected by hormones. The higher the androgen hormone is, the higher the sebum production will be as the androgen hormone is suspected to affect the keratinization process [10]. The increased sebum production and abnormal keratinocyte proliferation could result in obstruction of ducts and primary acne lesions as microcomedones. On the other side, the elevated sebum could lead to the colonization of $C$. acnes which in turn worsen acne vulgaris [11].

\section{Conclusion}

According to the results and discussion of the obtained data, the following conclusions were made:

1. There is an association between skin types and acne vulgaris Oily skin are 5 times more prone to acne vulgaris

2. Those with acne vulgaris predominantly have oily skin $(67,7 \%)$ than dry skin $(10,8 \%)$

3. Those with oily skin are predominantly aged 15 year-old $(38,7 \%)$

4. Those with oily skin are predominantly female $(44,1 \%)$

5. Those suffering from acne vulgaris are predominantly aged 15 year-old $(38,7 \%)$

6. Those suffering from acne vulgaris are predominantly female $(39,8 \%)$ 
[1] Kraft, J., Freiman, A., 2011. 'Management of acne.' CMAJ, vol 183, pp E430-E435.

[2] Dhamayanti, M., 2009. 'Overview adolescent health problems and services', Adolescent Health National Symposia: Current Challenges in Management. Vol.2.

[3] Anggrenni, O. 2012. 'Studi Retrospektif Pasien Akne Vulgaris di RSUP H.Adam Malik Medan periode tahun 2010-2012', Tesis Program Magister Kedokteran Klinik, Universitas Sumatera Utara.

[4] Baumann, L., 2016. 'Validation of a Questionnaire to Diagnose the Baumann Skin Type in All Ethnicities and in Various Geographic Locations'. Journal of Cosmetics, Dermatological Sciences and Applications vol 6 no.1 pp34.

[5] Del Rosso, J.Q., 2013. 'The Role of Skin Care as an Integral Component in the Management of Acne Vulgaris: Part 1: The Importance of Cleanser and Moisturizer Ingredients, Design, and Product Selection.' J. Clin. Aesthetic Dermatol. Vol.6, pp 19-27.

[6] Munawar S, Afzal M, Aftab M, Rizvi F, dan Chaudry MA.2009. 'Precipitating Factors of Acne Vulgaris in Females'. Ann. Pak. Inst. Med. Sci, Vol. 5(2), pp 104-107.

[7] Agravat, S.V., Pillai, A., 2018. 'Acne Vulgaris: An Insight.' International Journal of Pharmaceutical Sciences and Research. vol 9 no.8 pp 3530-3534.

[8] Shetage, S.S., Traynor, M.J., Brown, M.B., Raji, B., Raji, M., Kalio, D.G., Chilcott, R.P., 2014. 'Effect of ethnicity, gender and age on the amount and composition of residual skin surface components derived from sebum, sweat, and epidermal lipids.' Skin Research and Technology. vol. 20 no. 1 pp. 97-107.

[9] Abdallah, M.A.R., Zuelfakkar, N.M., Elbana, R.H., 2017. 'Comparative Study of Male and Female Sebum Production'. The Egyptian Journal of Hospital Medicine. Vol.69 no.2 pp. 1874-1879.

[10] Suva, M., 2015. 'A Brief Review on Acne Vulgaris: Pathogenesis, Diagnosis and Treatment.' Res. Rev. J. Pharmacol. vol 4, pp 1-12.

[11] Lavers, I., 2014. 'Diagnosis and management of acne vulgaris.' Nurse Prescr.vol 12, pp 330336. 